\title{
Effects of tissue-specific biomolecules on piglets after-weaning period
}

\author{
Ekaterina Romanovna Vasilevskaya(D, Liliya Vyacheslavovna Fedulova(i), Irina Mikhailovna Chernukha (D,
} Elena Alexandrovna Kotenkova(i) and Angelina Igorevna Fokina(i)

\author{
V. M. Gorbatov Federal Research Centre for Food Systems of RAS, Moscow, Russia. \\ Corresponding author: Ekaterina Romanovna Vasilevskaya, e-mail: rina715@yandex.ru \\ Co-authors: LVF: I.fedulova@fncps.ru, IMC: imcher@inbox.ru, EAK: lazovlena92@yandex.ru; AIF: anfo.moscow@gmail.com \\ Received: 04-09-2020, Accepted: 01-12-2020, Published online: 21-01-2021
}

doi: www.doi.org/10.14202/vetworld.2021.168-175 How to cite this article: Vasilevskaya ER, Fedulova LV, Chernukha IM, Kotenkova EA, Fokina AI (2021) Effects of tissue-specific biomolecules on piglets after-weaning period, Veterinary World, 14(1): 168-175.

\begin{abstract}
Background and Aim: Now-a-days antibiotics are the main tool for correcting the pathological conditions of pigs; unfortunately, antibiotics are a potential threat to the environment, as they lead to the spread of antibiotic-resistant infections. This study aimed to study the immunomodulatory encapsulated biomolecules on piglets in the post-weaning period.

Materials and Methods: An immunomodulator based on biomolecules obtained from animal raw materials included in alginate capsules to improve absorption has been developed. The study presents the results of a study on 25 weaned piglets (25-30 days old) which received biomolecules at a dose of $200 \mathrm{mg} / \mathrm{piglet}$ for 14 days, followed by $400 \mathrm{mg} / \mathrm{piglet}$ from days 15 to 28 . Blood was taken from animals for analysis (biochemical, hematological, cytometric, and enzyme immunoassay) and the integral index of blood serum antimicrobial activity was determined.
\end{abstract}

Results: Experimental animals, whose initial weight was 1.6 times less than that of the control animals, were able to bridge this gap and, on the $28^{\text {th }}$ day, there were no differences in weight. Stimulation of the production of cytokines interleukin (IL)-2 and IL-4 was observed and the antimicrobial resistance of blood serum to Escherichia coli also increased. A positive effect on the metabolism of piglets was noted, which helped them adapt to a change in diet (from colostrum to solid food).

Conclusion: The results show that the immunomodulation at the dose of $150 \mathrm{mg} / \mathrm{kg}$ body weight has a great potential for improving weaned pigs.

Keywords: biomolecules, health, immune system, pig, sustainable pork production.

\section{Introduction}

One of the basic critical needs of veterinary medicine and animal husbandry is prevention and control of the spread of existing and newly emerging pathogens. Treatment and preventive measures aimed at reducing the risk of infection with infectious diseases traditionally include vaccination and antibiotic therapy, including feed antibiotics [1]. The use of antibiotics in animal husbandry, as a panacea, leads to an increase in the cases of microorganisms with multiple resistance that has not even had direct contact with antibiotic agents, due to the acquisition of resistance genes (r-genes and plasmids) [2-4]. It is worth noting that even if a specific antibiotic is no longer introduced into the environment, r-genes are stored in bacteria, which have since been replicated without continuous exposure $[5,6]$. Thus, the inappropriate use of antibiotics in animal husbandry entails the accumulation in the surrounding section of highly resistant pathogens, mostly epizootically not relevant, but is latent threat of emergent infections that are dangerous

Copyright: Vasilevskaya, et al. Open Access. This article is distributed under the terms of the Creative Commons Attribution 4.0 International License (http://creativecommons.org/licenses/ by/4.0/), which permits unrestricted use, distribution, and reproduction in any medium, provided you give appropriate credit to the original author(s) and the source, provide a link to the Creative Commons license, and indicate if changes were made. The Creative Commons Public Domain Dedication waiver (http:// creativecommons.org/publicdomain/zero/1.0/) applies to the data made available in this article, unless otherwise stated. for both animals and humans. In addition, treatment of infectious diseases that arise by transmission of resistant pathogens to people through a polluted environment and agricultural products is complicated by the lack of response to treatment with modern chemotherapeutic agents [7].

In recent years, the main trend of the world scientific community is the search for effective and safe natural drugs with anti-inflammatory and immunomodulatory effects, which are aimed at increasing the body's resistance and enhancing the immune system [8-10].

We have shown the possibility of creating a new class of drugs - non-specific immunity stimulants, based on tissue- and species-specific biomolecules isolated from Sus scrofa immune organs using water with a modified isotopic $(\mathrm{D} / \mathrm{H})$ composition as a solubilizing agent $[11,12]$. The proteomic studies performed allowed us to identify more than 20 functional proteins in the spectrum of the isolated biomolecules, which are included in the immune response mechanism, exhibiting antioxidant. and anti-inflammatory properties, as well as stimulating metabolic processes in the body [13]. Efficacy of the resulting biomolecule complex has been shown by in vivo experiments on laboratory rats using a cyclophosphamide-induced immunodeficiency model. The main mechanism was stimulation of the production of cytokines by thymic immune cells as well as production of antibodies by B-system cells. Furthermore, an increase in non-specific resistance as 
well as in the adaptive capacity of productive animals were also noted $[14,15]$.

Weaning of piglets from the sow is practiced in pig farming to intensify production. The pronounced consequences of early weaning and at low body weight (BW) are inhibition of growth, a decrease in the body's resistance and a sharp increase in morbidity, which lead to significant death of animals [16]. This study aimed to examine the immunomodulatory potential of encapsulated biomolecules on piglets in the post-weaning period.

\section{Materials and Methods \\ Ethical approval}

The experimental protocols used in the current study were reviewed and approved by the Bioethical Committee of V. M. Gorbatov Federal Research Centre for Food Systems of RAS, Moscow, Russian Federation (2/2019).

\section{Study period and location}

The experiment was conducted at the V. M. Gorbatov Federal Research Centre for Food Systems

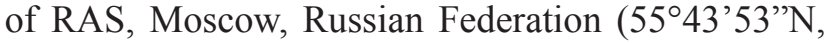
$\left.37^{\circ} 40^{\prime} 44^{\prime \prime} \mathrm{E}\right)$ during the period from October 10 to November 20, 2019.

\section{Isolation of bioactive components}

Bioactive components, including proteins and peptides, were obtained as previously described [15]. The technology includes extraction of Sus scrofa thymus, spleen, and lymph nodes by water-salt solution $(0.9 \% \mathrm{NaCl})$ containing $50 \mathrm{ppm}$ deuterium, after which the extracts are purified and frozen at $-40^{\circ} \mathrm{C}$.

Due to the influence of the isotopic composition of water on the biological properties and total extra-activity of proteins and peptides, water with deuterium concentration of $50 \mathrm{ppm}$ was used for the extraction [12]. Molecular composition was characterized as described by Fedulova et al. [13], including $\alpha$-thymosin (C3VVV8_PIG), rho GDP-dissociation inhibitor 1 (ARHGDIA $)+$ Acetyl (Protein N-term), rho GDP-dissociation inhibitor 2 (ARHGDIB), serpin B9 (SERPINB9), tyrosine kinase-binding protein (TYRO) and calnexin (CNX), C-terminus cathepsin $\mathrm{S}$ (STSS), myeloid differentiation primary response protein (MyD88), and transgelin (TAGLN), among others.

Tissue-specific biomolecules immobilized into alginate capsules were prepared on the basis of the technology developed by Manjanna et al. [17]. In brief, sodium alginate (Ruskhim, Russia) was dissolved in distilled water containing protein-peptide complexes (with a protein concentration in the solution of $21 \pm 2 \mathrm{~g} / \mathrm{L}$ ) until a final concentration of alginate of $1.2 \%$ by weight was achieved using a laboratory dispersion unit (Laboteks, Russia). The resulting suspension was passed using a peristaltic pump (Shenchenlab 2015 MCSeries, China) with a tube diameter of $1.5 \mathrm{~mm}$ and nozzle with a hole diameter of $0.15 \mathrm{~mm}$ in a $2 \%$ solution of calcium chloride (AppliChem Panreac, Germany) with a final $\mathrm{pH}$ of the solution equal to 4.0 (adjustment to the target $\mathrm{pH}$ was performed with $1 \mathrm{M}$ $\mathrm{NaOH})$. Next, the obtained capsules that were continuously mixed for $30 \mathrm{~min}$ on an MM-5 magnetic stirrer (Russia), washed with distilled water, and freeze-dried (INEY-4, Russia) at a temperature of $-40 \pm 2^{\circ} \mathrm{C}$ and pressure of $3.3 \mathrm{kPa}$.

\section{Experimental plan}

The study on pigs was performed in the Krolinfo LLC laboratory animal resource Center (NoLikinoDulyovo, Russia). Twenty-five male Vietnamese pot-bellied $\times$ Wiesenau weaned pigs with an initial BW of $2.3 \pm 1.40 \mathrm{~kg}$ and initial age (weaning age) of 25-30 days were used for a 4-week experiment. Piglets were labeled with ear tags with numbers from 1 to 25 . Weighing was performed with electronic floor scales MIDL “Gulliver 12” (MIDLiK, Russia) [18].

For this study, two groups of piglets were formed: Low-weight piglets (less than $2.0 \mathrm{~kg}$ ) were selected into the experimental group and larger piglets (more than $2.0 \mathrm{~kg}$ ) were selected into the control group. Pigs of the experimental group $(\mathrm{n}=15,1.70$ [1.37-1.85] $\mathrm{kg})$ were individually treated orally for 28 days with encapsulated biomolecules at a dose of $150.0 \mathrm{mg}$ capsules per kg BW. Pigs in the control group ( $\mathrm{n}=10$, $2.72[2.22-2.95] \mathrm{kg}$ ) were treated with an equivalent volume of water for 28 days.

The piglets were housed individually in an environmentally controlled nursery with hard plastic slatted flooring and fed ad libitum. The pig houses were kept clean and all the piglets were of a healthy status. Experimental animals were all negative for relevant infections (Bordetella bronchiseptica; Leptospira spp.; Pasteurella multocida; Salmonella spp.; Streptococci beta-hemolutic; Escherichia coli; and Toxoplasma gondii).

The temperature in the room throughout the experiment was $24 \pm 1^{\circ} \mathrm{C}$. Throughout the experiment, all piglets were fed SK-7 full-feed compound (Russia), which contained barley (40.5\%), wheat (26.0\%), wheat bran (18.0\%), sunflower meal ( $\leq 36 \%$ crude protein) $(5.0 \%)$, wheat-based feed grain product $(5.0 \%)$, soy protein concentrate $(2.0 \%)$, limestone flour $(2.0 \%)$, premix P52-1 (1.0\%), and table salt $(0.5 \%)$ (Table-1). The feed pellets were steamed in a mixture of milk and boiling water before each feeding.

Weighing and veterinary examination of animals was performed on days $0,7,14$, and 21. Blood samples for studies were taken in the morning from the jugular vein on days 0,14 , and 28 before feeding.

\section{Hematology assays}

A general clinical analysis of whole blood was performed on an Abacus Junior Vet 2.7 automatic veterinary hematology analyzer (Diatron Messtechnik $\mathrm{GmbH}$, Austria). The following blood parameters were assayed: white blood cell count, red blood cell 
Table-1: Nutrient specifications of piglet feed.

\begin{tabular}{lccclc}
\hline Item, unit & Amount & Vitamin, unit & Amount & Mineral, mg/kg & Amount \\
\hline Crude protein, \% & 15.00 & A, UI/kg & 3000 & Iron & 5.00 \\
Crude fiber, \% & 7.00 & D3, UI/kg & 500 & Manganese & 3.00 \\
Lipid, \% & 2.90 & E, mg & 3.0 & Zinc & 22.00 \\
Available lysine, \% & 0.45 & B2, mg & 3.0 & Cooper & 6.00 \\
Available methionine + cystine, \% & 0.38 & B3, mg & 7.0 & Cobalt & 0.50 \\
& & B5, mg & 385 & Iodine & 0.40 \\
Digestible energy, kcal/g & 2.52 & B12, mg & 0.025 & Selenium & 0.15 \\
\hline
\end{tabular}

(RBC) count, hemoglobin (HGB), hematocrit (HCT), platelet (PLT), plateletcrit (PCT), and mean platelet volume (MPV) [15].

\section{Flow cytometry}

The functional activity of leukocytes (relative content of lymphocytes, granulocytes, and monocytes) was determined on a Guava easyCyte automatic flow cytometer (Merck Millipore, Germany) [15].

\section{Biochemical assays}

The pig blood serum biochemical parameters, including total protein (TP), albumin (A), creatinine $(\mathrm{Cr})$, urea $(\mathrm{U})$, direct bilirubin $(\mathrm{DBr})$, aspartate aminotransferase (AST), alanine transaminase (ALT), lactate dehydrogenase, gamma-glutamyltransferase (GGT), alkaline phosphatase (ALP), triglyceride (TGr), total cholesterol (TC), and glucose (G), were determined on a BioChem FC-360 automatic biochemical analyzer (HTT, USA) using reagent kits (HTT, USA) [19].

\section{Enzyme-linked immunosorbent assay (ELISA)-tests}

An ELISA was performed on an Immunochem 2100 analyzer (USA) using the sandwich method with ELISA species-specific reagent kits (pigs) in order to cytokines interleukin (IL)-2 and IL-4 [15].

\section{Blood serum antimicrobial activity (BSAA)}

To study the animal resistance on $28^{\text {th }}$ day of the experiment, the integral index of BSAA was determined using a culture of E. coli. E. coli ( $24 \mathrm{~h}$ culture) preparation, which consists of a dilution to $2 \times 10^{9} \mathrm{CFU}$ in $1 \mathrm{~mL}$ of sterile saline solution (ZOMZ, Russia), followed by addition of $10 \mu \mathrm{L}$ of the microbial suspension obtained to $4.5 \mathrm{~mL}$ of meat-peptone broth and incubation for $24 \mathrm{~h}$ (daily culture broth) [20].

Into sterile tubes containing $4.5 \mathrm{~mL}$ of meatpeptone broth, $1 \mathrm{~mL}$ of test serum was added. Next, $0.1 \mathrm{~mL}$ of $E$. coli ( $24 \mathrm{~h}$ culture) was added to all tubes; $2 \mathrm{~mL}$ was taken from each sample; and the optical density was measured at $420 \mathrm{~nm}$. The mixture remaining in the tubes was incubated at $37^{\circ} \mathrm{C}$ for $180 \mathrm{~min}$. Next, $2 \mathrm{~mL}$ was also taken from each sample and the absorbance was measured at $420 \mathrm{~nm}$. The control was a test tube with serum-free meat and peptone broth. BSAA was expressed in growth inhibition units (conventional units) in accordance with the formula:

$\mathrm{BSAA}=100 \times\left(\mathrm{E}_{\mathrm{op} 3}-\mathrm{E}_{\mathrm{op} 0}\right) /\left(\mathrm{E}_{\mathrm{k} 3}-\mathrm{E}_{\mathrm{k} 0}\right)$,

Where $\mathrm{E}_{\mathrm{op} 0}$ is the optical density of the experimental sample before incubation;
$\mathrm{E}_{\mathrm{op} 3}$ is the optical density of the experimental sample after $3 \mathrm{~h}$ of incubation;

$\mathrm{E}_{\mathrm{k} 0}$ is the optical density of the control sample before incubation;

$\mathrm{E}_{\mathrm{k} 3}$ is the optical density of the control sample after $3 \mathrm{~h}$ of incubation.

\section{Statistical analysis}

Statistical processing of the results was performed with STATISTICA software program Versions 10.0 (Dell, USA). Intergroup comparison was performed by non-parametric Mann-Whitney test, with pairwise comparison within groups done by Wilcoxon signed-rank test. Results are presented as median (Me) and interquartile range ([P25-P75]) [21].

\section{Results}

Despite the significantly lower mass of Group 2 animals relative to control animals at the zeropoint ( 1.6 times at $\mathrm{p}<0.001$ ), on the $28^{\text {th }}$ day, the piglets did not differ significantly in weight (Table-2). Experimental animals of both groups gained weight stably for 4 weeks. The weight of piglets in the $1^{\text {st }}$ and $2^{\text {nd }}$ weeks of the experiment was $2.72(2.22-2.95) \mathrm{kg}$ and 2.90 (2.63-3.20) $\mathrm{kg}$ for Group 1 and 1.70 (1.37$1.85) \mathrm{kg}$ and $1.98(1.61-2.13) \mathrm{kg}$ for Group 2. In weeks 3 and 4, the animals' weight was up to 3.81 (2.97$5.14) \mathrm{kg}$ and 3.96 (3.64-5.57) kg in Group 1; however, in Group 2, there was a sharp increase in weight to $2.96(2.37-3.49) \mathrm{kg}$ and 3.37 (3.05-4.44) $\mathrm{kg}(33.1 \%$ at $\mathrm{p}<0.001$ and $12.2 \%$ at $\mathrm{p}=0.064$ ). High weight gain in week 3 caused the increased final weight gain in Group 2 animals, as a result of which their mass reached the values of piglets in the control group.

In Group 1 animals, following the analysis of the hematological parameters on the $14^{\text {th }}$ day relative to day 0 , a $40 \%$ decrease in PLT, 35.6\% decrease in PCT, and $16.3 \%$ decrease in MPV, were observed. On the $28^{\text {th }}$ day, relative to the $14^{\text {th }}$ day, a $21.2 \%$ increase in HGB was observed.

Moreover, in Group 2 animals, on the $14^{\text {th }}$ day relative to day 0 , a $25.1 \%$ increase in erythrocyte level, 29.1\% increase in HGB, and $23.9 \%$ increase in HCT, were observed (Tables-3 and 4); PLT decreased by $25.1 \%$ and PCT decreased by $31.9 \%$. On the $28^{\text {th }}$ day, PLT continued to decrease by $34.4 \%$ relative to day 14 and PCT also decreased by $34.7 \%$.

There were marked changes in animal blood serum biochemical markers, which characterize 
Table-2: BW and weight gain of piglets (Me [P25-P75]).

\begin{tabular}{|c|c|c|c|c|c|c|}
\hline \multirow[t]{2}{*}{ Group } & \multirow{2}{*}{$\begin{array}{c}\text { Initial BW, } \\
\mathbf{k g}\end{array}$} & \multirow[t]{2}{*}{ Final BW, skg } & \multicolumn{3}{|c|}{ Weekly weight gain, \% } & \multirow{2}{*}{$\begin{array}{l}\text { Final weight } \\
\text { gain, \% }\end{array}$} \\
\hline & & & 1 & 2 & 3 & \\
\hline 1 & $\begin{array}{c}2.54 \\
(2.06-2.64)\end{array}$ & $\begin{array}{c}3.96 \\
(3.64-5.57)\end{array}$ & $\begin{array}{c}7.13 \\
(6.50-13.64)\end{array}$ & $\begin{array}{c}9.07 \\
(6.40-13.64)\end{array}$ & $\begin{array}{c}31.57 \\
(15.53-43.90)\end{array}$ & $\begin{array}{c}69.79 \\
(53.70-91.17)\end{array}$ \\
\hline 2 & $\begin{array}{c}1.54 * \\
(1.24-1.66)\end{array}$ & $\begin{array}{c}3.37^{\mathrm{ns}} \\
(3.05-4.45)\end{array}$ & $\begin{array}{c}15.29 * \\
(12.33-19.04)\end{array}$ & $\begin{array}{c}17.32 * \\
(12.69-20.72)\end{array}$ & $\begin{array}{c}73.13^{\text {ns }} \\
(11.49-127.44)\end{array}$ & $\begin{array}{c}150.85 \\
(72.35-285.63)\end{array}$ \\
\hline
\end{tabular}

$*_{p}<0.05$ compared to group $1 . B W=$ Body weight, $n s=$ Non-significant

Table-3: Hematological parameters and serum biochemistry of experimental piglets (Me).

\begin{tabular}{|c|c|c|c|c|c|c|}
\hline \multirow[t]{2}{*}{ Parameter } & \multirow[t]{2}{*}{ Group } & \multicolumn{3}{|c|}{ Control points } & \multicolumn{2}{|c|}{ p-value } \\
\hline & & $\begin{array}{c}\text { T0 } \\
\text { (0 days) } \\
\end{array}$ & $\begin{array}{c}\text { T1 } \\
\text { (14 days) } \\
\end{array}$ & $\begin{array}{c}\text { T2 } \\
\text { (28 days) } \\
\end{array}$ & $\begin{array}{c}\text { T0 versus } \\
\text { T1 } \\
\end{array}$ & $\begin{array}{c}\text { T1 versus } \\
\text { T2 } \\
\end{array}$ \\
\hline \multirow[t]{2}{*}{ White blood cells, $10^{9} / \mathrm{L}$} & 1 & 23.17 & 25.16 & 26.38 & 0.100 & 0.433 \\
\hline & 2 & 20.14 & 25.65 & 30.22 & 0.069 & 0.204 \\
\hline \multirow[t]{2}{*}{ Red blood cells, $10^{12} / \mathrm{L}$} & 1 & 7.12 & 6.84 & 6.27 & 0.167 & 0.161 \\
\hline & 2 & 5.19 & 6.93 & 6.68 & $<0.001$ & 0.424 \\
\hline \multirow[t]{2}{*}{ Hemoglobin, g/L } & 1 & 87.50 & 104.00 & 111.00 & 0.126 & $<0.001$ \\
\hline & 2 & 79.00 & 111.50 & 114.50 & $<0.001$ & 0.416 \\
\hline \multirow[t]{2}{*}{ Hematocrit, \% } & 1 & 22.66 & 27.67 & 28.88 & 0.279 & 0.073 \\
\hline & 2 & 22.33 & 29.33 & 30.64 & 0.004 & 0.228 \\
\hline \multirow[t]{2}{*}{ Platelets, $10^{9} / \mathrm{L}$} & 1 & 837.01 & 502.50 & 485.50 & 0.007 & 0.218 \\
\hline & 2 & 819.50 & 614.00 & 403.00 & $<0.001$ & 0.003 \\
\hline \multirow[t]{2}{*}{ Plateletcrit, \% } & 1 & 0.59 & 0.38 & 0.37 & 0.007 & 0.296 \\
\hline & 2 & $0.72^{\text {ns }}$ & $0.49 *$ & $0.32^{\mathrm{ns}}$ & 0.004 & 0.014 \\
\hline \multirow[t]{2}{*}{ Mean platelet volume, $\mu \mathrm{m}^{3}$} & 1 & 8.01 & 6.70 & 7.20 & 0.014 & 0.647 \\
\hline & 2 & $6.80^{\text {ns }}$ & $7.95 *$ & $7.45^{\mathrm{ns}}$ & 0.315 & 0.949 \\
\hline \multirow[t]{2}{*}{ Total protein, g/L } & 1 & 62.10 & 59.00 & 55.68 & 0.028 & 0.465 \\
\hline & 2 & $64.90^{\mathrm{ns}}$ & $61.00^{\text {ns }}$ & $62.90 *$ & 0.005 & 0.889 \\
\hline \multirow[t]{2}{*}{ Albumin, g/L } & 1 & 43.20 & 35.75 & 30.95 & 0.013 & 0.109 \\
\hline & 2 & $46.40^{*}$ & $40.75^{*}$ & $37.18^{*}$ & 0.002 & 0.176 \\
\hline \multirow[t]{2}{*}{ Creatinine, $\mu \mathrm{M}$} & 1 & 64.05 & 49.25 & 51.38 & 0.005 & 0.465 \\
\hline & 2 & 57.80 & 52.30 & 54.75 & 0.023 & 0.093 \\
\hline \multirow[t]{2}{*}{ Urea, $\mu \mathrm{M}$} & 1 & 7.75 & 3.96 & 3.05 & 0.005 & 0.465 \\
\hline & 2 & $7.81^{\text {ns }}$ & $4.78^{*}$ & $4.96 *$ & 0.001 & 0.069 \\
\hline \multirow{2}{*}{ Direct bilirubin, $\mu \mathrm{M}$} & 1 & 2.56 & 2.08 & 2.26 & 0.114 & 1.000 \\
\hline & 2 & $4.41 *$ & $3.20 *$ & $2.45^{\mathrm{ns}}$ & 0.156 & 0.401 \\
\hline \multirow{2}{*}{ Aspartate aminotransferase, E/L } & 1 & 28.55 & 35.45 & 36.40 & 0.203 & 1.000 \\
\hline & 2 & $45.10 *$ & $28.20^{\text {ns }}$ & $46.65^{\text {ns }}$ & 0.027 & 0.208 \\
\hline \multirow[t]{2}{*}{ Alanine transaminase, $\mathrm{E} / \mathrm{L}$} & 1 & 26.25 & 34.70 & 28.05 & 0.114 & 0.273 \\
\hline & 2 & $47.30 *$ & $27.40^{\text {ns }}$ & $26.43^{\text {ns }}$ & $<0.001$ & 0.093 \\
\hline \multirow[t]{2}{*}{ Lactate dehydrogenase, E/L } & 1 & 463.40 & 459.80 & 522.40 & 0.646 & 0.273 \\
\hline & 2 & $587.20 *$ & $439.1^{\text {ns }}$ & $539.60^{\text {ns }}$ & 0.005 & 0.017 \\
\hline \multirow[t]{2}{*}{ Gamma-glutamyltransferase, E/L } & 1 & 41.34 & 30.48 & 26.11 & 0.013 & 0.068 \\
\hline & 2 & $41.57^{\text {ns }}$ & $42.96^{\mathrm{ns}}$ & $37.95 *$ & 0.691 & 0.484 \\
\hline \multirow[t]{2}{*}{ Alkaline phosphatase , E/L } & 1 & 317.35 & 150.55 & 124.35 & 0.007 & 0.715 \\
\hline & 2 & $432.05^{\mathrm{ns}}$ & $165.10^{\text {ns }}$ & $250.95 *$ & 0.001 & 0.025 \\
\hline \multirow[t]{2}{*}{ Triglyceride, M } & 1 & 0.27 & 0.46 & 0.72 & 0.333 & 0.144 \\
\hline & 2 & $0.45^{*}$ & $0.54^{\mathrm{ns}}$ & $1.13^{*}$ & 0.426 & 0.012 \\
\hline \multirow[t]{2}{*}{ Total cholesterol, M } & 1 & 8.41 & 5.56 & 2.24 & 0.007 & 0.144 \\
\hline & 2 & $7.32^{\text {ns }}$ & $5.30^{\mathrm{ns}}$ & $3.08 *$ & $<0.001$ & 0.093 \\
\hline \multirow[t]{2}{*}{ Glucose, mM } & 1 & 7.45 & 1.98 & 3.40 & 0.005 & 0.273 \\
\hline & 2 & 7.50 & 2.39 & 4.75 & 0.036 & 0.933 \\
\hline
\end{tabular}

${ }^{*} \mathrm{p}<0.05$ compared to Group 1. ns=Non-significant

protein metabolism, on the $14^{\text {th }}$ day of the experiment. In Group 1, a 5.0\% decrease in TP, $17.2 \%$ in A, 23.1\% in $\mathrm{Cr}$, and $48.9 \%$ in $\mathrm{U}$, was observed. In Group 2 animals, a similar trend was noted, as a $6.0 \%$ decrease in $\mathrm{TP}, 12.2 \%$ in $\mathrm{A}, 9.5 \%$ in $\mathrm{Cr}$, and $38.8 \%$ decrease in $\mathrm{U}$ was observed. When comparing these indicators on the $14^{\text {th }}$ and $28^{\text {th }}$ days, no significant changes were noted; however, a tendency of increased $\mathrm{Cr}$ and $\mathrm{U}$ in Group 2 animals was revealed.
Intergroup comparison in Group 2 animals on the $14^{\text {th }}$ and $28^{\text {th }}$ days revealed significant increases in A by $12.3 \%$ and $16.8 \%$ as well as in $U$ by $17.1 \%$ and $38.5 \%$, respectively. TP also increased on the $28^{\text {th }}$ day by $11.5 \%$.

For enzyme parameters in Group 1 , on the $14^{\text {th }}$ day, the activity of GGT decreased by $26.3 \%$ and that of ALP decreased by $52.6 \%$. In Group 2 animals, on the $14^{\text {th }}$ day, activity of AST decreased by $37.5 \%$, ALT 
Available at www.veterinaryworld.org/Vol.14/January-2021/22.pdf

Table-4: Hematological parameters and serum biochemistry of experimental piglets (P25-P75).

\begin{tabular}{|c|c|c|c|c|c|c|}
\hline \multirow[t]{2}{*}{ Parameter } & \multirow[t]{2}{*}{ Group } & \multicolumn{3}{|c|}{ Control points } & \multicolumn{2}{|c|}{ p-value } \\
\hline & & T0 (0 days) & T1 (14 days) & T2 (28 days) & $\begin{array}{c}\text { T0 versus } \\
\text { T1 }\end{array}$ & $\begin{array}{c}\text { T1 versus } \\
\text { T2 }\end{array}$ \\
\hline \multirow[t]{2}{*}{ White blood cells, $10^{9} / \mathrm{L}$} & 1 & $20.44-26.17$ & $19.83-30.24$ & $22.91-33.66$ & 0.100 & 0.433 \\
\hline & 2 & $17.03-24.26$ & $21.07-28.45$ & $25.17-31.65$ & 0.069 & 0.204 \\
\hline \multirow[t]{2}{*}{ Red blood cells, $10^{12} / \mathrm{L}$} & 1 & $4.27-7.71$ & $6.32-7.33$ & $5.72-7.14$ & 0.167 & 0.161 \\
\hline & 2 & $4.49-6.43$ & $6.31-7.40$ & $5.94-7.60$ & $<0.001$ & 0.424 \\
\hline \multirow[t]{2}{*}{ Hemoglobin, g/L } & 1 & $79.75-108.25$ & $93.50-113.00$ & $98.75-119.25$ & 0.126 & $<0.001$ \\
\hline & 2 & $63.00-95.50$ & $102.00-121.50$ & $102.50-126.00$ & $<0.001$ & 0.416 \\
\hline \multirow[t]{2}{*}{ Hematocrit, \% } & 1 & $20.81-28.47$ & $24.03-31.87$ & $25.70-31.28$ & 0.279 & 0.073 \\
\hline & 2 & $17.83-26.78$ & 25.94-33.49 & $26.86-35.46$ & 0.004 & 0.228 \\
\hline \multirow[t]{2}{*}{ Platelets, $10^{9} / \mathrm{L}$} & 1 & $566.75-1315.50$ & $403.50-725.50$ & $291.75-771.50$ & 0.007 & 0.218 \\
\hline & 2 & $607.00-2266.00$ & $533.25-928.50$ & $295.00-618.75$ & $<0.001$ & 0.003 \\
\hline \multirow[t]{2}{*}{ Plateletcrit, \% } & 1 & $0.37-1.26$ & $0.30-0.46$ & $0.19-0.55$ & 0.007 & 0.296 \\
\hline & 2 & $0.35-2.36^{\mathrm{ns}}$ & $0.39-0.68 *$ & $0.22-0.50^{\mathrm{ns}}$ & 0.004 & 0.014 \\
\hline \multirow[t]{2}{*}{ Mean platelet volume, $\mu \mathrm{m}^{3}$} & 1 & $6.28-10.63$ & $6.20-7.60$ & $6.35-7.73$ & 0.014 & 0.647 \\
\hline & 2 & $6.30-11.35^{\mathrm{ns}}$ & $6.83-8.38 *$ & $7.13-8.10^{\mathrm{ns}}$ & 0.315 & 0.949 \\
\hline \multirow[t]{2}{*}{ Total protein, g/L } & 1 & $60.43-69.03$ & $57.38-60.83$ & $51.48-58.68$ & 0.028 & 0.465 \\
\hline & 2 & $63.65-68.65^{\mathrm{ns}}$ & $58.98-64.00^{\mathrm{ns}}$ & $59.40-65.48 *$ & 0.005 & 0.889 \\
\hline \multirow[t]{2}{*}{ Albumin, g/L } & 1 & $41.70-45.88$ & $34.18-38.88$ & $29.88-32.10$ & 0.013 & 0.109 \\
\hline & 2 & $44.80-49.45^{*}$ & $39.15-42.48^{*}$ & $36.65-38.55^{*}$ & 0.002 & 0.176 \\
\hline \multirow[t]{2}{*}{ Creatinine, $\mu \mathrm{M}$} & 1 & $58.30-68.45$ & $43.08-53.58$ & $47.92-55.31$ & 0.005 & 0.465 \\
\hline & 2 & $56.35-64.35$ & $48.70-55.05$ & $53.43-60.70$ & 0.023 & 0.093 \\
\hline \multirow[t]{2}{*}{ Urea, $\mu \mathrm{M}$} & 1 & $6.18-15.16$ & $3.30-4.50$ & $2.89-3.24$ & 0.005 & 0.465 \\
\hline & 2 & $6.12-13.03^{\mathrm{ns}}$ & $3.86-5.16 *$ & $4.66-5.33^{*}$ & 0.001 & 0.069 \\
\hline \multirow[t]{2}{*}{ Direct bilirubin, $\mu \mathrm{M}$} & 1 & $2.07-3.10$ & $1.78-2.40$ & $1.95-2.84$ & 0.114 & 1.000 \\
\hline & 2 & $3.73-5.89 *$ & $2.47-4.83 *$ & $2.01-2.73^{n s}$ & 0.156 & 0.401 \\
\hline Aspartate & 1 & $25.40-43.60$ & $31.55-47.48$ & $27.30-48.88$ & 0.203 & 1.000 \\
\hline aminotransferase, E/L & 2 & $39.60-58.35^{*}$ & $26.30-36.40^{\mathrm{ns}}$ & $35.78-57.53^{\text {ns }}$ & 0.027 & 0.208 \\
\hline \multirow[t]{2}{*}{ Alanine transaminase, E/L } & 1 & $22.90-33.48$ & $32.55-40.30$ & $27.53-34.30$ & 0.114 & 0.273 \\
\hline & 2 & $37.75-49.50 *$ & $23.20-44.60^{\mathrm{ns}}$ & $25.58-31.23^{\mathrm{ns}}$ & $<0.001$ & 0.093 \\
\hline \multirow{2}{*}{$\begin{array}{l}\text { Lactate dehydrogenase, } \\
\mathrm{E} / \mathrm{L}\end{array}$} & 1 & $458.83-530.33$ & $411.03-575.88$ & $411.93-624.48$ & 0.646 & 0.273 \\
\hline & 2 & 532.05-719.70* & $394.25-521.45^{\mathrm{ns}}$ & $525.35-638.90^{\mathrm{ns}}$ & 0.005 & 0.017 \\
\hline \multirow{4}{*}{$\begin{array}{l}\text { Gamma- } \\
\text { glutamyltransferase, E/L } \\
\text { Alkaline phosphatase, E/L }\end{array}$} & 1 & $39.50-44.37$ & $29.03-38.18$ & $24.33-29.00$ & 0.013 & 0.068 \\
\hline & 2 & $36.86-45.46^{n s}$ & $34.50-52.67^{\mathrm{ns}}$ & $32.56-41.09 *$ & 0.691 & 0.484 \\
\hline & 1 & $204.98-441.95$ & $111.65-166.80$ & $108.13-141.75$ & 0.007 & 0.715 \\
\hline & 2 & $279.30-507.18^{\mathrm{ns}}$ & $139.90-211.10^{\mathrm{ns}}$ & 188.93-308.38* & 0.001 & 0.025 \\
\hline \multirow[t]{2}{*}{ Triglyceride, M } & 1 & $0.24-0.46$ & $0.36-0.58$ & $0.62-0.85$ & 0.333 & 0.144 \\
\hline & 2 & $0.38-0.69 *$ & $0.44-0.66^{\mathrm{ns}}$ & $1.06-1.23 *$ & 0.426 & 0.012 \\
\hline \multirow[t]{2}{*}{ Total protein, M } & 1 & $5.72-11.33$ & $4.98-6.18$ & $2.09-2.43$ & 0.007 & 0.144 \\
\hline & 2 & $5.95-9.86^{\mathrm{ns}}$ & $4.50-5.65^{\mathrm{ns}}$ & $2.67-3.46 *$ & $<0.001$ & 0.093 \\
\hline \multirow{2}{*}{ Glucose, mM } & 1 & $7.05-8.35$ & $1.85-2.21$ & $3.05-3.98$ & 0.005 & 0.273 \\
\hline & 2 & $5.40-7.90$ & $2.06-2.78$ & $4.55-5.33$ & 0.036 & 0.933 \\
\hline
\end{tabular}

$* \mathrm{p}<0.05$ compared to Group 1. ns=Non-significant

by $42.1 \%$, LDH by $25.2 \%$, and ALP by $61.8 \%$. On the $28^{\text {th }}$ day, relative to the $14^{\text {th }}$ day, the activity of LDH and ALP increased by $22.9 \%$ and $52.0 \%$, respectively.

An intergroup comparison revealed that, in Group 2 animals, at the commencement of the experiment ( 0 day), $\mathrm{DBr}$ was increased by $41.9 \%$, AST by $36.7 \%$, ALT by $44.5 \%$, and LDH by $21.1 \%$. On day 14 , in Group 2, DBr was increased by $35.0 \%$; on the $28^{\text {th }}$ day, GGT and ALP activity increased by $31.2 \%$ and $50.4 \%$, respectively.

Changes were also noted among the parameters of lipid metabolism. On day 14, Groups 1 and 2 showed a decrease in TC by $33.9 \%$ and $27.6 \%$, respectively; on the $28^{\text {th }}$ day, TGr in Group 2 animals increased by $52.2 \%$. An intergroup comparison in Group 2 was done when the experiment had just begun and a $40 \%$ increase in TGr was found. On the $28^{\text {th }}$ day, an increase in TGr (36.3\%) and TC (27.3\%) was noted.
Furthermore, $\mathrm{G}$ in the blood serum of animals of both groups on the $14^{\text {th }}$ day, relative to day 0 was decreased by $73.4 \%$ and $68.1 \%$, respectively. Animal blood leukocyte typing revealed the absence of significant changes both in the intergroup comparison and in comparison of parameters on the $14^{\text {th }}$ and $28^{\text {th }}$ days (Figure-1).

ELISA test of cytokine level in Group 2 animals' blood serum revealed a $70.2 \%$ increase in IL-2 level on the $14^{\text {th }}$ day relative to day 0 and a $25.2 \%$ increase on the $28^{\text {th }}$ day relative to the $14^{\text {th }}$ day. IL-4 level increased on the 28 th day relative to the $14^{\text {th }}$ day by $82.0 \%$ (Table-5).

At the end of the experiment, BSAA index was $71.03(62.15-82.24)$ units for Group 1 animals and 52.34 (50.47-53.27) units for Group 2 animals, thus indicating increased bactericidal activity in Group 2 animals' blood serum. 


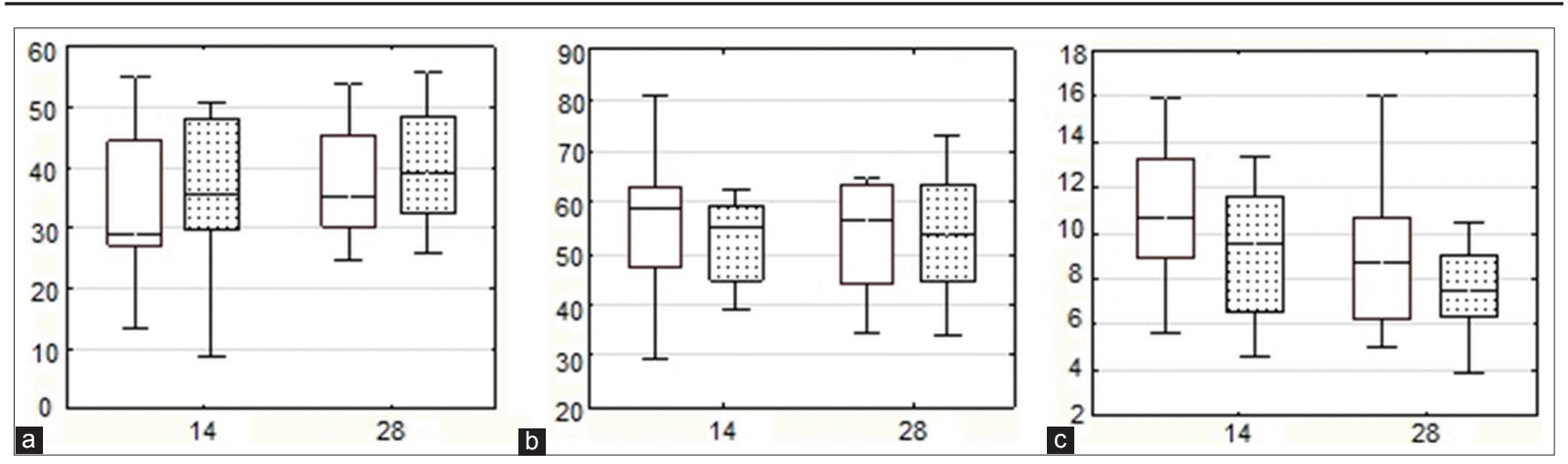

Figure-1: Relative content of lymphocytes (LIM), granulocytes (GRAN), and monocytes (MON) in piglet blood on the $14^{\text {th }}$ and $28^{\text {th }}$ days: (a) LIM, \%; (b) GRAN, \%; (c) MON, \%. Data presented as box plots include hinges extending from the $25^{\text {th }}$ to $75^{\text {th }}$ percentiles, the median line within the box and whiskers extending to the minimum and maximum values of the dataset. Group 1 - white boxes, Group 2 - boxes with black dots.

Table-5: Immunoassay analysis of cytokines (Me [P25-P75]).

\begin{tabular}{|c|c|c|c|c|c|c|}
\hline \multirow[t]{2}{*}{ Parameter } & \multirow[t]{2}{*}{ Group } & \multicolumn{3}{|c|}{ Control points } & \multicolumn{2}{|c|}{ p-value } \\
\hline & & T0 (0 days) & T1 (14 days) & T2 (28 days) & $\begin{array}{c}\text { T0 versus } \\
\text { T1 } \\
\end{array}$ & $\begin{array}{c}\text { T1 versus } \\
\text { T2 }\end{array}$ \\
\hline \multirow[t]{2}{*}{$\mathrm{IL}-2, \mathrm{pg} / \mathrm{mL}$} & 1 & $\begin{array}{c}634.27 \\
(292.98-815.98)\end{array}$ & $\begin{array}{c}795.72 \\
(709.79-1217.10)\end{array}$ & $\begin{array}{c}946.29 \\
(647.82-2093.14)\end{array}$ & 0.114 & 0.333 \\
\hline & 2 & $\begin{array}{c}352.02 \\
(199.02-493.32)\end{array}$ & $\begin{array}{c}1182.24 \\
(847.92-1611.18)\end{array}$ & $\begin{array}{c}1580.07 \\
(1158.58-2505.14)\end{array}$ & 0.001 & 0.023 \\
\hline \multirow[t]{2}{*}{$\mathrm{IL}-4, \mathrm{pg} / \mathrm{mL}$} & 1 & $\begin{array}{c}63.14 \\
(29.44-78.45)\end{array}$ & $\begin{array}{c}42.14 \\
(33.03-49.09)\end{array}$ & $\begin{array}{c}41.37 \\
(32.60-104.54)\end{array}$ & 0.203 & 0.333 \\
\hline & 2 & $\begin{array}{c}18.90 \\
(13.14-35.84)\end{array}$ & $\begin{array}{c}21.01 \\
(19.55-33.64)\end{array}$ & $\begin{array}{c}116.83 \\
(54.53-180.02)\end{array}$ & 0.311 & 0.002 \\
\hline
\end{tabular}

$\mathrm{IL}=$ Interleukin

\section{Discussion}

The use of antibiotics often leads to the development of side effects and spread of antibiotic-resistant diseases. This study investigated the effectiveness of natural immunomodulatory biomolecules included in alginate capsules.

The study results prove the efficiency of encapsulated biomolecules as an immunomodulator. Experimental piglet-weaners reached the control animals' weight in 28 days, thus overcoming the initial weight difference (by 1.6 times) [22]; moreover, there were increases in blood component antimicrobial activity (including BSAA) and cytokine production as well as the absence of pronounced changes in the immune system [23]. The clinical experiment showed an increase in the content of IL-2 and IL-4 as well as antimicrobial activity with stable levels of leukocytes and young immune cells, thus indicating an increase in functional activity, first of all, in the humoral immune system [24].

In addition, in this study, the increases in $\mathrm{RBC}$ and HGB at the $28^{\text {th }}$ day of the experiment in Group 2 are similar to the values reported in other publications $[25,26]$ and it correlates with a weight gain increase of more than $70 \%$ at 3 experimental weeks. Changes in PLT and erythrocyte markers for piglets, accompanied by individual parameter variability in each experimental group, especially on days $0-14$, which is reflected in a wide interquartile range, are associated with intensive growth of animals and maturation of their hematopoietic system. The decrease in PLT count in piglets in our study, starting from the $2^{\text {nd }}$ experimental week, is consistent with the observations of other studies [27,28]. This trend may indicate an increase in the production of large PLTs by bone marrow megakaryocytes due to the activation of thrombopoiesis by biomolecules [29].

In this study, we found that the use of biomolecules for weaned piglets had a positive effect on protein synthesis in the liver, as evidenced by TP and A levels in serum normalization. According to $\mathrm{Yu}$ et al., this is the result of adaptation of animal protein metabolism in connection with the transition from breast milk to animal feed and because it is also associated with the rapid growth of piglets, leading to a rapid increase in muscle mass. In their article, they demonstrated similar changes in protein metabolism in recently weaned piglets [30]. A decrease in enzyme activity indicated by hepatic markers, coupled with a decrease in protein and $\mathrm{Cr}$ levels, can reflect the metabolic status of hepatic protein in response to dietary changes in weaned piglets [31].

According to a previous study [32], an increase in ALP concentration in young animals is probably associated with higher osteoblast activity; however, this effect needs to be clarified.

As established in the control animals, hypoproteinemia, hypoalbuminemia, hypoglycemia, 
hypoureaemia, hypercreatininemia, and hyperbilirubinemia with a decrease in blood enzyme activity indicate the difficulty of adaptation of piglets' metabolic processes during ration changing to solid food (animal feed). Biomolecules had a positive effect on the gluconeogenesis process in pigs, as evidenced by an increase in serum $G$ levels; moreover, there was a net positive influence on the pigment-forming function of the liver and functioning of the liver and biliary tract, as evidenced by a decrease in total bilirubin and activity of the aminotransferases ALT and AST as well as and ALP and GGT.

\section{Conclusion}

The antimicrobial activity of the blood serum increased significantly after taking the immunomodulator. The level of cytokines involved in the immunity of piglets also increased. In general, the immunomodulator favorably affects the metabolism of animals and reduces exposure to stress. It was shown that biomolecules can cause a positive effect on the adaptation of piglets' metabolism during transition from colostrum to solid food by improving the functional activity of the liver, particularly by increasing protein synthesis.

\section{Authors' Contributions}

ERV and LVF were responsible for conception and design of the study. EAK and AIF coordinated the analysis. IMC was responsible for the conclusive and final remarks. ERV and LVF did the final editing and approval along with researchers. All authors read and approved the final manuscript.

\section{Acknowledgments}

This research was performed with financial support from the Russian Science Foundation, Russia (project No. 15-16-00008).

\section{Competing Interests}

The authors declare that they have no competing interests.

\section{Publisher's Note}

Veterinary World remains neutral with regard to jurisdictional claims in published institutional affiliation.

\section{References}

1. Sandbulte, M.R., Spickler, A.R., Zaabel, P.K. and Roth, J.A. (2015) Optimal use of vaccines for control of influenza a virus in swine. Vaccines, 3(1): 22-73.

2. Nhung, N.T., Van, N.T.B., Cuong, N.V., Duong, T.T.Q., Nhat, T.T., Hang, T.T.T., Nhi, N.T.H., Kiet, B.T., Hien, V.B., Ngoc, P.T., Campbell, J., Thwaites, G. and Carrique-Mas, J. (2018) Antimicrobial residues and resistance against critically important antimicrobials in non-typhoidal Salmonella from meat sold at wet markets and supermarkets in Vietnam. Int. J. Food Microbiol., 266:301-309.

3. Nelson, M.I. and Vincent, A.L. (2015) Reverse zoonosis of influenza to swine: New perspectives on the human-animal interface. Trends Microbiol., 23(3): 142-153.

4. Messele, Y.E., Abdi, R.D., Yalew, S.T., Tegegne, D.T.,
Emeru, B.A. and Werid, G.M. (2017) Molecular determination of antimicrobial resistance in Escherichia coli isolated from raw meat in Addis Ababa and Bishoftu, Ethiopia. Ann. Clin. Microbiol. Antimicrob., 16(1): 55.

5. Shousha, A., Awaiwanont, N., Sofka, D., Smulders, F.J., Paulsen, P., Szostak, M.P., Humphrey, T. and Hilbert, F. (2015) Bacteriophages isolated from chicken meat and the horizontal transfer of antimicrobial resistance genes. Appl. Environ. Microbiol., 81(14): 4600-4606.

6. Rahimi, E., Jalali, M. and Weese, J.S. (2014) Prevalence of Clostridium difficile in raw beef, cow, sheep, goat, camel and buffalo meat in Iran. BMC Public Health, 14:119.

7. Schmidt, J.W., Agga, G.E., Bosilevac, J.M., BrichtaHarhay, D.M., Shackelford, S.D., Wang, R., Wheeler, T.L. and Arthur, T.M. (2015) Occurrence of antimicrobial-resistant Escherichia coli and Salmonella enterica in the beef cattle production and processing continuum. Appl. Environ. Microbiol., 81(2): 713-725.

8. Subramaniam, S., Selvaduray, K.R. and Radhakrishnan, A.K. (2019) Bioactive compounds: Natural defense against cancer? Biomolecules, 9(12): 758.

9. Smith, R.A., Zhu, X., Shartle, K., Glick, L. and M'ikanatha, N.M. (2017) Understanding the public's intentions to purchase and to persuade others to purchase antibiotic-free meat. Health Commun., 32(8): 945-953.

10. Ruwali, P., Ambwani, T.K. and Gautam, P. (2018) In vitro immunomodulatory potential of Artemisia indica Willd. in chicken lymphocytes. Vet. World, 11(1): 80-87.

11. Basov, A., Fedulova, L., Vasilevskaya, E. and Dzhimak, S. (2019) Possible mechanisms of biological effects observed in living systems during $2 \mathrm{H} / 1 \mathrm{H}$ isotope fractionation and deuterium interactions with other biogenic isotopes. Molecules, 24(22): 4101.

12. Basov, A., Fedulova, L., Baryshev, M. and Dzhimak, S. (2019) Deuterium-depleted water influence on the isotope $2 \mathrm{H} / 1 \mathrm{H}$ regulation in body and individual adaptation. Nutrients, 11(8): 1903.

13. Fedulova, L., Elkina, A., Vasilevskaya, E. and Barysheva, E. (2018) Identification of tissue-specific proteins of immunocompetent organs of Sus scrofa isolated in deuterium depleted medium. Med. Sci., 22(94): 509-513.

14. Fedulova, L.V., Basov, A.A., Vasilevskaya, E.R. and Dzhimak, S.S. (2019) Gender difference response of male and female immunodeficiency rats treated with tissue-specific biomolecules. Curr. Pharm. Biotechnol., 20(3): 245-253.

15. Fedulova, L.V., Vasilevskaya, E.R., Kotenkova, E.A., Elkina, A.A., Baryshev M.G. and Lisitsyn A.B. (2017) Influence of different polypeptides fractions derived from Sus scrofa immune organs on the rats immunological reactivity. J. Pharm. Nutr. Sci., 7(2): 35-40.

16. Cilek, S. (2015) Effective factors on survival rate of malya lambs (11/16 akkaraman x 5/16 deutsches merinofleischschaf). Indian J. Anim. Sci., 85(10): 1112-1116.

17. Manjanna, K.M., Pramod Kumar, T.M. and Shivakumar, B. (2010) Calcium alginate cross-linked polymeric microbeads for oral sustained drug delivery in arthritis. Drug Discov. Ther., 4(2): 109-122.

18. Zhang, H.J., Jiang, X.R., Mantovani, G., Valdez Lumbreras, A.E., Comi, M., Alborali, G., Savoini, G., Dell'Orto, V. and Bontempo, V. (2016) Modulation of plasma antioxidant activity in weaned piglets by plant polyphenols. Ital. J. Anim. Sci., 13(2): 3242.

19. Kotenkova, E., Vasilevskaya, E., Barysheva, E., Chernukha, I. and Lisitsyn, A. (2020) Changes in blood and inner organs of immunodeficient rats induced by complex of natural peptides and proteins with immunostimulating activity. Med. Sci., 24(105): 3655-3663.

20. Crokaert, F., Lismont, M.J., van der Linden, M.P. and Yourassowsky, E. (1988) Determination of serum bactericidal activity against Escherichia coli by an automated photometric method. J. Clin. Microbiol., 26(10): 2069-2076. 
21. Fay, M.P., Brittain, E.H., Shih, J.H., Follmann, D.A. and Gabriel, E.E. (2018) Causal estimands and confidence intervals associated with Wilcoxon-Mann-Whitney tests in randomized experiments. Stat. Med., 37(20): 2923-2937.

22. Faustini, M., Bronzo, V., Maffeo, G., Russo, V., Munari, E. and Vigo, D. (2003) Reference intervals and age-related changes for platelet count, mean platelet volume and plateletcrit in healthy pre-weaning piglets in Italy. J. Vet. Med., 50(9): 466-469.

23. Klem, T.B., Bleken, E., Morberg, H., Thoresen, S.I. and Framstad, T. (2010) Hematologic and biochemical reference intervals for Norwegian crossbreed grower pigs. Vet. Clin. Pathol., 39(2): 221-226.

24. Bhattarai, S. and Nielsen, J.P. (2015) Association between hematological status at weaning and weight gain post-weaning in piglets. Livest. Sci., 182:64-68.

25. Yu, K., Canalias, F., Solà-Oriol, D., Arroyo, L., Pato, R., Saco, Y., Terré, M. and Bassols, A. (2019) Age-related serum biochemical reference intervals established for unweaned calves and piglets in the post-weaning period. Front. Vet. Sci., 6:123.

26. Xie, Y., Zhang, Q., Wang, L., Wang, Y., Cheng, Z., Yang, Z. and Yang, W. (2019) The effects of partially or completely substituted dietary zinc sulfate by lower levels of zinc methionine on growth performance, apparent total tract digestibility, immune function, and visceral indices in weaned piglets. Animals (Basel), 9(5): 236.

27. Perri, A.M., O’Sullivan, T.L., Harding, J.C., Wood, R.D. and Friendship, R.M. (2017) Hematology and biochemistry reference intervals for Ontario commercial nursing pigs close to the time of weaning. Can. Vet. J., 58(4): 371-376.

28. Pliszczak-Król, A., Rząsa, A., Gemra, M., Król, J., Łuczak, G., Zyzak, A., Zalewski, D., Iwaszko-Simonik, A. and Graczyk, S. (2016) Age-related changes of platelet and plasma coagulation parameters in young pigs. J. Vet. Diagn. Invest., 28(5): 561-567.

29. Ventrella, D., Dondi, F., Barone, F., Serafini, F., Elmi, A., Giunti, M., Romagnoli, N., Forni, M. and Bacci, M.L. (2017) The biomedical piglet: Establishing reference intervals for haematology and clinical chemistry parameters of two age groups with and without iron supplementation. BMC Vet. Res., 13(1): 23.

30. Soler, C., Goossens, T., Bermejo, A., Migura-García, L., Cusco, A., Francino, O. and Fraile, L. (2018) Digestive microbiota is different in pigs receiving antimicrobials or a feed additive during the nursery period. PLoS One, 13(5): e0197353.

31. Sundareswaran, L., Srinivasan, S., Wankhar, W. and Sheeladevi, R. (2017) Effect of Scoparia dulcis on noise stress induced adaptive immunity and cytokine response in immunized Wistar rats. J. Ayurveda Integr. Med., 8(1): 13-19.

32. Camp Montoro, J., Manzanilla, E.G., Solà-Oriol, D., Muns, R., Gasa, J., Clear, O. and Calderón Díaz, J.A. (2020) Predicting productive performance in grow-finisher pigs using birth and weaning body weight. Animals, 10(6): 1017 . 